osophical development, his early orthodoxy, his period of doubt, his attempt to support his religious beliefs by reasoning, and his final adoption of a faith philosophy, all these are admirably presented with abundant citations from Tennyson's works. Tennyson's philosophical discussions are grouped under the problems of God, freedom and immortality.

Both these volumes are of interest and value to students of the history of philosophy and the history of poetry.

Col,UMBIA UnIVERSITY.

Adam Leroy Jones.

\title{
PSYCHOLOGY OF RELIGION.
}

The Contents of Religious Experience. James H. Leuba. The Monist, Vol. XI., No. 4, July, I9or.

Observations de psychologie religieuse. Th. Fuournoy. Archives de Psychologie, II., 8, October, I903.

Professor Leuba's article is one of the series of papers on the psychology of religion coming from time to time from his pen. The paper is, as the author states, a mere survey of the materials he had in hand, consisting of a number of autobiographical accounts of religious experience, "with the unpretentious purpose of gathering a few general impressions which may serve as a preparation for the more systematic investigation to come. It is, accordingly, little more than samples of the data collected, accompanied with a few comments." The fourteen religious autobiographies transcribed illustrate almost as many types of religiosity, and give one a glimpse of the varieties of religious experience.

The comments fall for the most part into two classes - the first pertaining to the relation of intellectual belief to religious life. "The frequent inconsistencies," writes Professor Leuba, "the unmeaning explanations, and the oft-recurring negative answers, indicate how little reflection is given to religion, how much it is a matter of uncontrolled impulse. $* * *$ The supremacy of the fundamental life impulses over the directions of the intellect, of the unconscious over the conscious, affirms itself with uncontestable significance in these records; not what is objectively real or what is logical, but that which ministers to the approved needs and desires is the 'religiously' true." After pointing out, in the documents he has collected, the influence that the desire or 'will to believe' often has over religious conviction, and the inclination to construct one's ideas of the Diety according to one's own needs, the author concludes: "Truth for the natural man, is 
that which secures the result wanted; its criterion is affecto-motor efficiency. Whatever regard we have for objective truth and logical consistency is evidently due to the practical benefits derived from conforming our conduct to their requirements." The fact that these comments are abstracted from actual religious experience bars them from the realm of the commonplace. Indeed, the chief value of Professor Leuba's work is, that it is a serious effort to find out the real contents of the religious consciousness of our contemporaries, and thus to transform empirical opinion about religious life into scientific knowledge.

The other class of comments relate to the meaning or end of religious activity. We cannot do better than give in the author's own words what seems to him the chief philosophical conclusion of his paper.

"The end of religion is not the worship of God as some like to put it. *** The fact is that when God, conjured up by the needs of the worshipper, appears before him, his hands stretch forth in request for power or mercy, not in adoration. And, preposterous as it may seem, it is yet true that he cares very little who God is, or even whether he is at all. *** The truth of the matter may be put this way: God is not known, he is not understood: He is used-used a good deal and with an admirable disregard of logical consistency, sometimes as meat-purveyor, sometimes as moral support, sometimes as friend, sometimes as an object of love. If $\mathrm{He}$ proves himself useful, his right to remain in the service of man is thereby vindicated. The religious consciousness asks no more than that. Not God, but life, more life, a larger, richer, more satisfying life, is in last analysis the end of religion. The love of life at any and every level of development, or, to use another phraseology, the instinct for preservation and increase, is the religious impulse. It would appear, then, that there is at bottom no specifically 'religious' impulse; the preservation and increase of life is the moving impulse as well of religious as of secular activity.

"How could men have to come to think that " the vital element in all religions is the conviction that the existence of the world, with all it contains and all that surrounds it, is a mystery ever pressing for interpretation?' On the contrary, the mystery of the world is resolutely thrust aside by consciousness in so far as it is, and as long it remains, religious. *** The pious soul may, and often does, leave its supplicating attitude to turn for a while to philosophy, but it then ceases to be religious and becomes philosophic. For a moment it yearns, 
it desires, it supplicates, it wills; for another moment it is critical and asks whys and wherefores - then religious, now philosophic, in as close succession as you please. In the twinkling of an eye it passes from the one to the other attitude; they alternate but they cannot coexist. They differ just as much and in the same way as desiring differs from thinking, or willing from reasoning. Considered merely from its intellectual side, the religions attitude postulates, the other inquires."

In the Observations de Psychologie religieuse $M$. Flournoy has made a valuable contribution to the data available for the psychological study of religion. The paper consists of six religious autobiographies, with sundry remarks and explanations by the author relating to the various points touched upon in the different accounts. There is nothing in the experiences set forth that is striking or remarkable one finds in the data merely the commonplace and normal experiences of commonplace and normal persons. Indeed M. Flournoy states at the outset that 'it is with ordinary and commonplace natures that psychology and its practical applications (pedagogy, etc.) are concerned primarily, in the endeavor to understand and guide these; and the analysis of extraordinary cases is of importance only as it leads to a more far-reaching knowledge of the ordinary human mind.'

"The accounts," says M. Flournoy, "are too disparate to admit of any general conclusions apart from those dealing with the relation of intellectual beliefs (dogma, theological conceptions, etc.) to the more deep-seated phenomena of the emotional and volitional order." Apart from the documents themselves, the chief interest of the paper centers in the comments which the author makes upon this relationship. He finds two extreme types that illustrate very clearly the differences that can exist between religious persons in respect to the ròle played by doctrinal belief. Between these extremes one finds an infinite diversity of intermediary positions.

"There are persons," M. Flournoy writes, "for whom a fixed and well-determined doctrinal system is felt to be a necessary condition, a sine quo non of religious life. *** This type of individual gives the central place in his religion to a system of intellectual affirmations, swallowed whole through a faith in some external authority, and serving as the touch-stone, as the regulator, of all his moral and religious life. For these, religious evolution consists mainly in ridding themselves of the intellectual shell that surroundings and education have put upon them, in order to leave their immediate inner experience free to expand in whatever way it will." A mysterious 
reality, inaccessible even when it is present to one, which falls under no intellectual category, not even that of personality, but a living reality that calls forth one's prayer and answers it, that stimulates one to acts of courage, that goes to the very root of one's being, the source of life and joy - this holds the central place in the life of these persons, and performs functions essential to them - one may almost say biological functions. On account of its value and vital importance to them, these persons do not hesitate to accept such experience as true. They find a purity and a transcendance in their religious life that satisfies their needs.

M. Flournoy likewise calls attention to the fact that the 'doubts' so often referred to by religious persons, are never doubts of an intellectual nature. "These have to do with one's inner state, with the question of one's own safety, not with the truth of dogma." The latter are not questioned in the least. Religious evolution and crises take place in the deep vital sphere of the affective and moral nature, not in the realm of dogmatic belief. This point - that religion concerns itself with life rather than with the logical accuracy of the intellectual beliefs - is made by Professor Leuba also, in the article reviewed above.

M. Flournoy emphasizes another point insisted on by Professor Leuba - namely, the demand on the part of the individual that his religion recognize and satisfy his needs. "It is a constant psychological phenomenon that the gaps, the inconsistencies, even the contradictions of a system are no obstacles to its acceptance by all those who find in that system the counterpart of their own religious experience, the echo of their feelings, and the satisfaction of their needs. It seems that just that quality, the response to the many vital needs of the individual, is the only essential of such a system, and in proportion as it possesses this, he lets pass the inevitable incoherence which is to be found in every attempt at metaphysical systematization, from that of the humblest to that of the most profound thinker."

Columbus, Ohio.

Grace Latimer Jones.

\section{EXPERIMENTAL.}

Studies in the Psychology and Physiology of Learning. EDGAR SwrFr. American Journal of Psychology, Vol. XIV., pp. 20I252.

In this doctor's thesis are recorded the results of an experimental study of learning under the three heads of acquisition of skill, acquisition of information, and getting of motor control. 